\title{
SWAINSON'S HAWKS GATHER TO FORAGE AT FIRES ON A NORTHERN PRAIRIE
}

ROBERT K. MURPHY, Department of Biology, University of Nebraska at Kearney, Kearney, NE 68849, E-mail: <murphyrk@unk.edu>, and KAREN A. SMITH, U.S. Fish and Wildlife Service (retired), Lostwood National Wildlife Refuge, Kenmare, ND 58746, E-mail: <prairie@restel.net>

Swainson's Hawks characteristically soar over farm machinery during summer, searching for rodents and other prey that are exposed by disturbance to vegetation during cultivation, mowing, crop harvest and pesticide application. ${ }^{3,11}$ Estep suggests that this hawk also may forage in association with burning activities. ${ }^{4}$ During a 20 -year period, 1983-2002, we observed Swainson's Hawks and other species of hawks foraging at 158 prescribed burns conducted by us and co-workers to restore and maintain native, northern mixed-grass prairie at the $109-\mathrm{km}^{2}$ Lostwood National Wildlife Refuge (NWR) in northwest North Dakota $\left(48^{\circ}\right.$ $37^{\prime} \mathrm{N}, 102^{\circ} 27^{\prime} \mathrm{W}$ ). Our observations suggest that this hawk is attracted to smoke plumes and that fire may be an important part of its evolutionary ecology.

\section{Methods}

Prescribed burns were conducted during spring (late-April through midMay) or summer (mid-July through

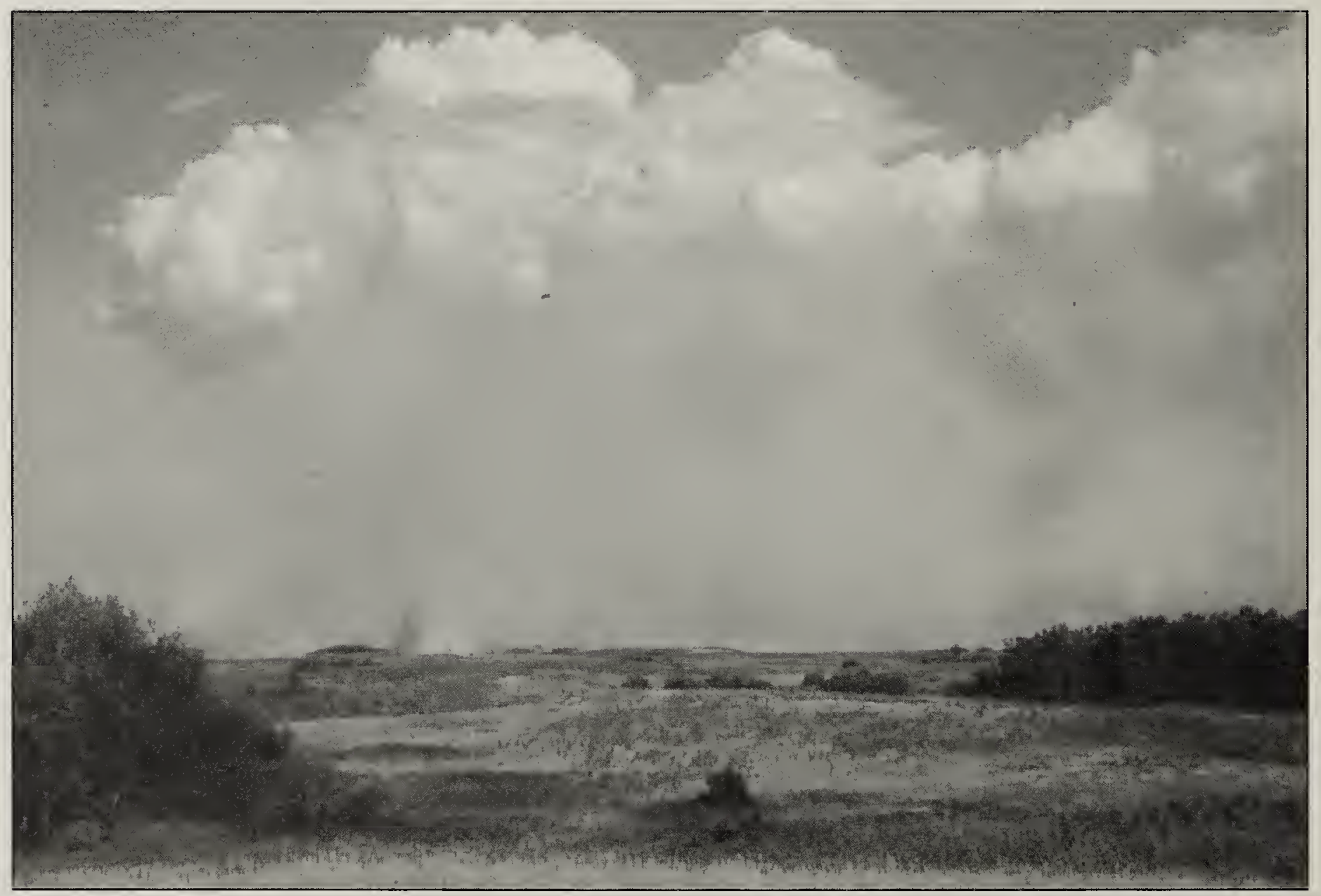

Figure 1. A prescribed burn on the 2250-ha Wilderness Area at Lostwood National Wildlife Refuge in nw North Dakota is large enough to create its own weather.

R. Murphy 


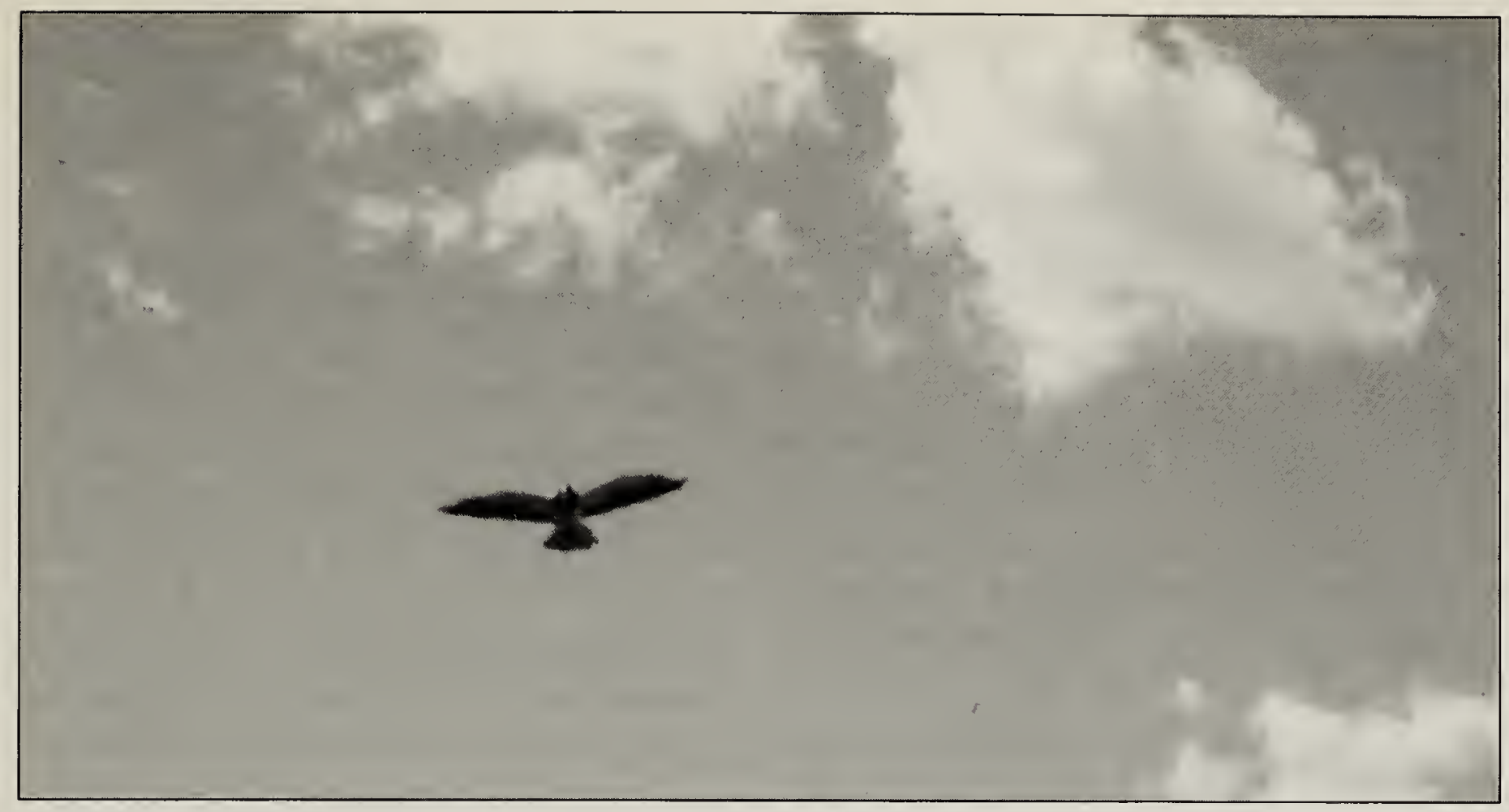

Figure 2. A Swainson's Hawk soars near a fire.

R. Murphy

early-September) and typically covered 65-400 ha, although as many as 2250 ha were burned in a day (Figure 1). Burns were conducted by a surroundfire approach: igniting a backing fire along the downwind side, backfiring along flanks, then setting a headfire downwind into the center of the area. Prescribed burns consumed $80-95 \%$ of above-ground vegetation, even when much green growth was present (e.g., in mid-May).

We ignited fires while afoot rather than from motorized vehicles, improving our opportunity to see and hear wildlife. Although we could not systematically survey hawks because we were helping conduct burns, we carried binoculars and noted approximate numbers of each species of hawk within burn areas. Hawks conspicuously soared and were readily counted at small burns (65-130 ha), but some likely were overlooked at large burns (400-2250 ha) where smoke often hindered visibility over much of the area.

\section{Results}

We observed Swainson's Hawks at every spring and summer burn (Figure
2). Typically, three to five Swainson's Hawks attended and foraged at a burn. One or two Red-tailed Hawks soared over most prescribed burns that were conducted in spring. Based on their behavior, especially territorial screaming, the Red-tailed Hawks usually appeared to be defending nest sites from people conducting the burns, rather than actively foraging. Swainson's Hawks were at least two to three times more common than Redtailed Hawks at prescribed burns in spring, even though nesting Red-tailed Hawks were three to five times more common than nesting Swainson's Hawks in the Lostwood NWR area (Swainson's Hawks, 3-7 pairs $/ 100$ km² $^{2}$ versus Red-tailed Hawks, 15-21 nesting pairs $/ 100 \mathrm{~km}^{2}$ ). ${ }^{10}$ We seldom observed Ferruginous Hawks, but the species was very uncommon in the area (about 1 nesting pair/100 km²). ${ }^{10}$

Swainson's Hawks were most numerous at burns conducted in spring as compared to burns later in the season. For example, we observed at least 13 Swainson's Hawks along with three Red-tailed Hawks and one Ferruginous Hawk foraging at a 323ha burn conducted May 15, 1989. 
Based on the known nesting distribution of hawks in the Lostwood area $^{10}$, we believe that some Swainson's Hawks traveled at least 10$15 \mathrm{~km}$ from their nesting territories to forage at this and other burns conducted after early May.

On a 46-ha burn on May 9, 1993, we observed at least 28 Swainson's Hawks plus two Red-tailed Hawks foraging on voles (Microtus spp.) and mice (probably Deer Mice, Peromyscus maniculatus). Near sunset, about $3 \mathrm{hr}$ after the burn, Swainson's Hawks were scattered over the blackened prairie, perched on the ground with their crops bulging. Some still were making short hop-flights after prey. At least five Swainson's Hawks continued to forage on the burn daily over the following 3 days. Because the timing of this burn coincided with the later migration period of Swainson's Hawks in the area that year, we surmised that most of the Swainson's Hawks had been migrating and were attracted to the burn by its smoke plume. On May 7, 2001 we burned 30 ha about $2 \mathrm{~km}$ north of the refuge. Seven Swainson's Hawks foraged simultaneously over the relatively small burn, appearing oblivious to each other and to us as we walked about the burn area.

The Swainson's Hawks we observed often used strong updrafts created by heat from the fires to rise rapidly to 50-100 $\mathrm{m}$ above ground after missing an attempt at prey. We often noted several Swainson's Hawks soaring close together (25-50 m apart) over a headfire or flank fire. Commonly, Swainson's Hawks flew less than $6 \mathrm{~m}$ above ground over the burned prairie, flapping and gliding much like a Northern Harrier. Late in the day, it was typical to see the hawks perched on the ground with distended crops, hopflying or running short distances after rodents, similar to when foraging on grasshoppers. ${ }^{7}$

\section{Discussion}

Swainson's Hawks are part of the unique community of birds that evolved, at least in part, in the temporally and spatially dynamic environment that characterized the presettlement northern Great Plains. ${ }^{8}$ Fire and bison grazing were frequent, widespread disturbances that reduced vegetation swiftly and dramatically, ${ }^{1,2}$ presumably making small animals vulnerable to highly mobile, wide-ranging predators including the Swainson's Hawk. The species appears to recognize smoke plumes as cues to foraging sites and may travel far to such sites, not unlike the White-tailed Hawk. ${ }^{9}$ In much of the contemporary northern Great Plains, the Swainson's Hawk nests in landscapes dominated by agriculture, 5 , 12 where frequent disturbance by bison herds and prairie fires largely have been replaced by disturbance associated with farm machinery. Firecaused disturbance to vegetation may be an important aspect of the evolutionary ecology of Swainson's Hawk and, as such, may help facilitate the species' modest ability to adopt an agricultural environment as breeding habitat.

1. BRAGG, T.B. 1995. The physical environment of Great Plains grasslands. In: A. Joern and K.A. Keeler (eds.), The Changing Prairie: North American Grasslands. Oxford University Press, New York. p. 49-81.

2. CAMPBELL, C., I.D. CAMPBELL, C.B. BLYTH, and J.H. MCANDREWS. 1994. Bison extirpation may have caused aspen expansion in western Canada. Ecography 17:360-362.

3. ENGLAND, A.S., M.J. BECHARD, and C.S. HOUSTON. 1997. Swainson's Hawk Buteo swainsoni. The Birds of North America.No.265. F.B. Gill and A. Poole (eds.). Academy of Natural Sciences, Philadelphia, Pennsylvania and American Ornithologists' Union, Washington, D.C. 
4. ESTEP, J.A. 1989. Biology, movements, and habitat relationships of the Swainson's Hawk in the Central Valley of California, 1986-87. California Department of Fish and Game, Nongame Bird and Mammal Report.

5. GROSKORTH, L.C. 1995. Nest-site selection by the Swainson's Hawk on the Regina plain, Saskatchewan. Canadian Journal of Zoology 73:1887-1890.

6. HIGGINS, K.F. 1986. Interpretation and compendium of historical fire accounts in the northern Great Plains. U.S. Fish and Wildlife Service, Resource Publication No. 161.

7. JOHNSON, C.G., L.A. NICKERSON, and M.J. BECHARD. 1987. Grasshopper consumption and summer flocks of nonbreeding Swainson's Hawks. Condor 89:676-678.
8. JOHNSGARD, P.A. 1978. The ornithogeography of the Great Plains states. Prairie Naturalist 10:97112.

9. KOPENY, M.T. 1988. White-tailed Hawk Buteo albicaudatus. In: R.S. Palmer (ed.), Handbook of North American birds, Volume 5. Yale University Press, New Haven, Connecticut. p. 74-84.

10. MURPHY, R.K. 1993. History, nesting biology, and predation ecology of raptors in the Missouri Coteau of northwestern North Dakota. Ph.D. Thesis, Montana State University.

11. PALMER, R.S. 1988. Swainson's hawk Buteo jamaicensis. In: R.S. Palmer (ed.), Handbook of North American birds, Volume 5. Yale University Press, New Haven, Connecticut. p. 48-73.

12. SCHMUTZ, J.K. 1989. Hawk occupancy of disturbed grasslands in relation to models of habitat selection. Condor 91:362-371

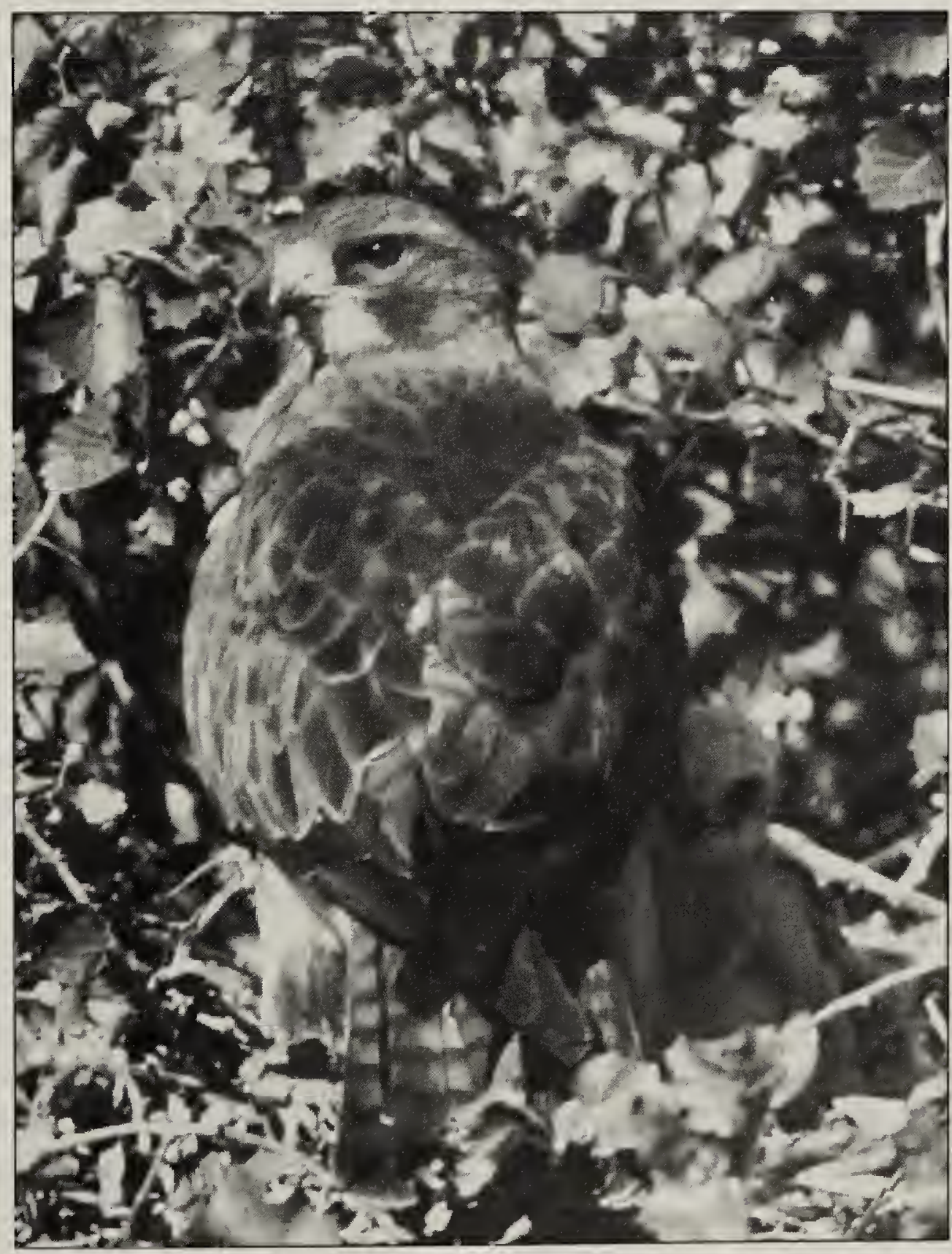

A Swainson's Hawk shades its chick in a nest in a hawthorn shrub at the refuge. R. Murphy 